\title{
2
}

\section{Entrepreneurship, the Rule of Law, and Protection of Property Rights}

\subsection{General Principles}

Today, almost 250 years after Thomas Paine stated that "in free countries the law ought to be king," the legal principle that a polity should not be governed by arbitrary decisions made by autocratic rulers or government officials is considered a central building block of a free society and essential for any country striving for prosperity (Bingham 2011). Possibly, the only competitor to the rule of law for the title of most fundamental economic institution is the protection of private property rights-the existence of legal titles to hold property and the protection thereof (North and Weingast 1989; Libecap 1993; Acemoglu et al. 2001, 2005; Rodrik et al. 2004; North et al. 2009; Besley and Ghatak 2010). In practice, these fundamental rules of the game strengthen and complement each other; when of sufficiently high quality, they prevent undue uncertainty and ensure that entrepreneurs can engage in productive activities. By contrast, weak rule of law and property rights protection within a country discourage entrepreneurs from making entrepreneurial discoveries and from (re)investing (retained) earnings in their ventures (Johnson et al. 2002). The division and specialization of labor are also hampered in such instances, to the detriment of collaborative innovation blocs and their actors, whether financiers, personnel, or customers.

That said, the rule of law is not enshrined in any particular legal rule; what happens in practice matters more than what the law says. Likewise, formal property rights that do not offer control rights in practice are useless, while the absence of formal property rights need not be prohibitive if control rights are sufficiently strong (Rodrik 2007). When assessing the current state of the 
rule of law and protection of property rights in Europe, therefore, a first guiding principle is legality, i.e., to consider de facto rather than de jure institutions (Feld and Voigt 2003; Acemoglu et al. 2005; Woodruff 2006). The distinction is crucial: while the acquis communautaire (the accumulated legislation, legal acts, and court decisions that constitute the body of EU law) ensure that a candidate member state's formal legal framework is more or less aligned before it is allowed to join the EU, differences among members in terms of the effective enforcement of the rule of law and property rights protection remain substantial.

Table 2.1 shows that the countries with the best judicial systems and the highest quality of government are the Nordic, Anglo-Saxon, and Benelux countries, followed by Germany and France. The Eastern bloc scores especially low on most survey items, but this is also true for Greece and Italy and, to a lesser extent, for Spain and Portugal. ${ }^{1}$ Table 2.1 also includes measures of government effectiveness and regulatory quality; as can be seen, countries rank similarly along these dimensions. Most importantly, however, the table highlights the distinction between de facto and de jure institutions, especially considering that the EU member states all share the same formal legal environment. The discrepancies have implications not only for the rule of law and the protection of property rights but also for a member state's overall ability to get things done (Hulten 1996; Aschauer 2000; WEF 2015).

Economic actors can (and do) compensate to some extent for weaknesses in the rule of law and property rights protection by undertaking more activity off-the-books; as a result, member countries that perform poorly in these respects have larger underground economies (Schneider 2015a; see Appendix Fig. A.1). In Bulgaria and Romania, the shadow economy is estimated to be approximately 30\% of official GDP, while in Northern European countries, the proportion is less than half of that. However, shadow economy activity is generally a poor substitute for formal sector activity, partly because it creates unfair competition for firms that adhere to rules and regulations. More importantly, firms in the shadow economy do not benefit from the division of labor and specialization of collaborative innovation blocs to the same extent as formal firms and are therefore unlikely to grow large.

\footnotetext{
${ }^{1}$ Suse and Hachez (2017, p. 79) point out that the concept of the rule of law represented by indicators such as these is thinner than the concept espoused by most international organizations. Specifically, the EU defines the rule of law as "a wider view of the legal system" that provides a stable framework protecting citizen's expectations and captures the populations' values and aspirations, ushering in a society free of violence and oppression.
} 
Table 2.1 The rule of law and the quality of government: four indicators for the EU member countries and the USA

\begin{tabular}{|c|c|c|c|c|}
\hline Country & Rule of law & $\begin{array}{l}\text { Security of } \\
\text { property rights }\end{array}$ & $\begin{array}{l}\text { Government } \\
\text { effectiveness }\end{array}$ & $\begin{array}{l}\text { Regulatory } \\
\text { quality }\end{array}$ \\
\hline Finland & 100.00 & 9.29 & 98.08 & 96.63 \\
\hline Sweden & 99.04 & 8.27 & 96.15 & 95.67 \\
\hline Denmark & 97.60 & 8.18 & 95.67 & 92.31 \\
\hline Netherlands & 97.12 & 8.68 & 96.63 & 98.56 \\
\hline Austria & 96.15 & 8.09 & 91.83 & 90.87 \\
\hline Luxembourg & 95.19 & 8.86 & 93.75 & 93.75 \\
\hline UK & 92.79 & 8.83 & 90.87 & 94.23 \\
\hline USA & 91.83 & 7.86 & 92.79 & 92.79 \\
\hline Germany & 91.35 & 7.60 & 94.23 & 95.19 \\
\hline France & 89.42 & 7.29 & 87.98 & 83.65 \\
\hline Ireland & 88.94 & 8.29 & 87.02 & 91.83 \\
\hline Belgium & 87.50 & 7.91 & 85.10 & 86.54 \\
\hline Estonia & 86.54 & 7.34 & 83.65 & 93.27 \\
\hline Malta & 85.10 & 6.88 & 80.77 & 87.98 \\
\hline Portugal & 84.13 & 6.15 & 87.50 & 79.33 \\
\hline Czech Rep. & 83.65 & 6.05 & 81.25 & 86.06 \\
\hline Slovenia & 82.69 & 5.63 & 84.62 & 72.12 \\
\hline Spain & 81.25 & 6.08 & 81.73 & 79.81 \\
\hline Lithuania & 80.77 & 5.57 & 80.29 & 83.17 \\
\hline Latvia & 80.29 & 5.06 & 78.85 & 82.69 \\
\hline Cyprus & 79.81 & 5.87 & 79.81 & 81.25 \\
\hline Slovakia & 71.63 & 5.23 & 75.00 & 76.44 \\
\hline Hungary & 70.19 & 3.84 & 70.19 & 73.08 \\
\hline Poland & 68.27 & 5.11 & 74.04 & 78.85 \\
\hline Romania & 63.94 & 5.64 & 46.15 & 70.19 \\
\hline Croatia & 63.46 & 4.38 & 72.60 & 68.75 \\
\hline Italy & 62.50 & 5.04 & 69.71 & 75.00 \\
\hline Greece & 56.73 & 4.81 & 66.35 & 62.98 \\
\hline Bulgaria & 51.92 & 4.18 & 63.94 & 72.60 \\
\hline
\end{tabular}

Note: Rule of law captures perceptions of the extent to which agents have confidence in and abide by the rules of society, in particular the quality of contract enforcement, property rights, the police, and the courts, as well as the likelihood of crime and violence. Security of property rights captures the extent to which individuals have secure rights to property, including the fruits of their labor. Government effectiveness captures perceptions of the quality of public and civil services and the degree of their independence from political pressures, the quality of policy formulation and implementation, and the credibility of the government's commitment to such policies. Regulatory quality captures perceptions of the ability of the government to formulate and implement sound policies and regulations that permit and promote private-sector development. All scores except for the security of property rights are standardized from 0 to 100, where the value 100 is assigned to the leading country. Singapore is the leading country for the third and Hong Kong is the leading country for the fourth measure

Source: World Bank, World Governance Indicators 2018 (based on the data for 2017), and Fraser Institute, Economic Freedom of the World 2018 Annual Report for security of property rights (based on the data for 2016) 
The second guiding principle we identify in this area is justifiability. It has been said that civilizations only flourish when attaining a balance between protecting expectations and allowing adaptation to new conditions (Kuran 1988 , p. 145): on one hand, we want to protect private property to incentivize productive investment through the accumulation of private wealth; on the other hand, it is necessary to maintain an open and contestable market for new entrants to keep unproductive rent seeking (e.g., lobbying for closed and complex standards) and destructive entrepreneurship (e.g., ventures that disregard public health, exploit natural resources, or appropriate other nonmarket goods) at bay. This balancing act is particularly important when applied to intellectual property rights (IPR), where one must weigh the interests of inventors against the positive spillover effects of knowledge diffusion. The rules of the game need to reward value creation but discourage pure rent seeking.

Because of their encompassing characteristics, safeguarding the rule of law and the protection of property rights requires (concerted) policy action at the local, regional, and national levels. As to the issues we shall discuss that relate to IPR, these mainly fall under the domain of national governments and the competencies of the EU in negotiating international treaties and regulations referring to IPR.

\subsection{Proposals}

Regarding the rule of law, the protection of property rights, and the effectiveness of government, laggard countries should do their utmost to converge towards the level of the best-performing countries. Such improvements are in the long-term best interest of all citizens in these countries, although powerful elites and interest groups may well have a short-term interest in blocking the process. The reality is that deficiencies in these factors negatively impact all agents in collaborative innovation blocs and induce people to conduct activities and hide their capital in the shadow economy. The poorest EU member states are high-medium-income countries, and even in the VoC literature, there is no support for the view that they can compensate for deficiencies in the most fundamental rules of the game through other institutional measures.

Proposal 1: Strengthen monitoring and enforcement mechanisms to improve and safeguard the performance of all member states on rule of law, protection of property rights, and government effectiveness. 
This proposal acknowledges the first guiding principle of focusing on legality. Unfortunately, even though the effective enforcement of the rule of law and property rights is the foundation of virtually all economic activity, this is not self-evident in all European member states. For example, the time it takes to settle civil court cases in Italy is prohibitively long (Sanders et al. 2018a), and institutional backsliding among new members once they have been admitted has been highlighted as a real concern (Suse and Hachez 2017). Imperfections in these institutions hurt all actors in the economy, but especially cash-constrained small and young ventures. Addressing such fundamental issues would go a long way towards supporting a more entrepreneurial and innovative economy.

These facts notwithstanding, the potential for the EU's formal admission process to promote the rule of law in candidate countries has been called into question; backsliding among admitted members such as Hungary and Poland is a case in point. One must, therefore, be "wary of expecting too much from rule of law promotion and should certainly not hope that full integration into a defined 'rule of law-compliant' model of legal system is possible" (Suse and Hachez 2017, p. 80). Hence, while the EU should urgently strive to find new methods to improve the legal frameworks in laggard countries, the fact remains that member states themselves control most matters pertaining to the de facto rule of law and the legal protection of property rights (Suse and Hachez 2017). As such, the efficiency of a country's government is an issue of paramount importance.

That said, the protection of private property rights can never be absolute. Such rights are continually renegotiated and need to be justified. For example, landowner property rights, which extended from hell below to heaven above in Roman times, were curtailed when the development of the airline industry required free airspace. Furthermore, many governments around the world have nationalized the ownership rights to minerals below a certain depth (the USA is a notable exception). Zoning laws, environmental regulations, and heritage protection restrict private property rights and prevent entrepreneurship from becoming a destructive force. In regard to preventing unproductive rent seeking and even destructive entrepreneurship (Baumol 1990; Desai et al. 2013; Sanders and Weitzel 2013), such restrictions are justified, provided a legitimate authority can set the rules transparently and enforce them neutrally: as long as the rules apply equally to all under the law, productive entrepreneurs can play by these rules and contribute to well-being.

It is particularly relevant to justify the IPR framework by balancing private incentives and public benefits. Knowledge is unique in the sense that it is often tedious and expensive to create. However, once discovered, it is nonrival 
in use and can be shared freely without being diminished. On one hand, if IPR protection is too weak or too easily circumvented, creators will need alternative ways to recover the costs of knowledge generation and early diffusion (Merrill et al. 2004; Acs and Szerb 2007; Baumol et al. 2007; Kauffman Foundation 2007). On the other hand, if protection is overly strong, the inventor or his delegate will extract excessive rents from entrepreneurs ex post. Such rents come about if the IPR time frame is too long or if it is too easy to obtain protection even for bits and pieces of potentially useful knowledge and inventions that have yet to be developed into useful innovations. Such features of IPR protection inhibit the free flow of knowledge and reduce incentives to commercialize, leaving the economy less competitive and less innovative as a consequence (Jaffe and Lerner 2004; Acs and Sanders 2012). Strong(er) IPR protection then becomes the problem rather than the solution, making it necessary to consider more fundamental reforms to the system itself to promote the diffusion and use of knowledge. In line with the principle of justifiability, we therefore propose the following:

Proposal 2: Limit the breadth, width, and span of patent protection to cover working prototypes and market-ready innovations only for a short period of time, and permit economic actors to infringe upon patents that have not been commercialized.

This proposal is quite fundamental and requires careful planning to ensure a smooth transition to the new situation. If implemented, it would limit the extent of IPR protection to strike a better balance between public and private interests following our guiding principle of justifiability. However, this is a big "if": the EU, after all, is party to international treaties that set minimum requirements for IPR, such as the WTO TRIPS Agreement. Of course, the EU should not violate or disregard these treaties. Instead, the Union should use its influence in the governing bodies to enable reforms in the desired direction. The limitations to patent rights would still fall well within the institutional structure in place but would significantly reduce the risk that entrepreneurs are being sued for infringements on patents they did not even know existed (Jaffe and Lerner 2004).

Moreover, in line with Schumpeter (1934), we believe that a substantial European bottleneck to innovation is found in commercial application of knowledge. As the knowledge spillover theory of entrepreneurship (Acs et al. 2009; Braunerhjelm et al. 2010) argues, commercial application is essential for knowledge spillover and diffusion. Thus, rebalancing IPR in favor of 
entrepreneurs to promote the diffusion of knowledge would be a move in the right direction.

Proposal 3: Require patent applicants to set the price for the license before the commercial application is known instead of allowing them to negotiate the terms of a license contract afterwards.

If this proposal became reality, it would clarify the division of labor within collaborative innovation blocs by making the entrepreneur the residual claimant to all the rents of commercialization, while the inventor would retain the right to claim the costs she incurred in knowledge generation. To the extent that commercialization is an innovation bottleneck, such reforms would increase the rate of innovation and growth (Acs and Sanders 2012).

Of course, patent protection works differently in different sectors and different stages of the industry life cycle. Some parts of the economy can achieve similar protection with trade secrets (e.g., software), whereas mandatory and highly uncertain certification procedures make it difficult to conceive of efficient alternatives to patents in other sectors (e.g., pharmaceuticals). It could perhaps be that the functions of patenting can be fulfilled more efficiently in other ways, and it certainly does not require allowing inventors to monopolize and thereby limit the profitable use of the knowledge they have generated. Nevertheless, given legal complexities and institutional complementarities, a cautious, experimental approach that retains the system's benefits while increasing the free flow of knowledge is advisable. Here, a promising venue is the introduction of the so-called "open source" patents, which would retain the functions of knowledge repository and verification while improving access to knowledge for commercial use (Boettiger and Burk 2004).

Proposal 4: Introduce and support existing experiments with open source patent registration.

This proposal is justified, as it restores the balance between the public interest in free knowledge disclosure and dissemination and the private interest in obtaining fair and just rewards for creating new knowledge. A public register and repository can help inventors claim fair (monetary and non-monetary) rewards while guaranteeing open and free access to non-rivalrous knowledge to ensure dynamic efficiency.

As for the implementation of proposals 2-4, treaties and case law in the EU already underline the importance of balancing the public interest and private property rights. Suse and Hachez $(2017$, p. 86$)$ note that " $[r]$ ecently, the 
[European Court of Justice] was faced with the question of a potential conflict between intellectual property rights and other rights relevant to entrepreneurship, such as the right to conduct a business (Article 16 Charter)." The conclusion of the case saw the Court insisting on imposing limits on the protection of intellectual property in the face of other (public) interests, in perfect alignment with the principle of justifiability.

The EU has strong competencies in (re)negotiating the treaties that govern IPR at the international level. It is hard, if not impossible, for individual member states, let alone the regions or localities within them, to deviate from such international arrangements. The Union must therefore first negotiate for the space to experiment before member states and lower polities can engage in such experimentation. And while Brexit means that the UK will leave the EU, Germany is also a major patenting nation whose role in international treaty negotiations should not be underestimated (see Sanders et al. 2018b, c for a more detailed analysis of these issues).

\subsection{Summary}

Table 2.2 summarizes the principles presented in this chapter together with the proposals derived from them and the level(s) at which political action should take place to make them a reality. Because the rule of law and protection of property are encompassing characteristics of the institutional environment for entrepreneurs, the first proposal will require (concerted) policy action at the local, regional, and national levels. Put differently, effective enforcement at the national level is likely to be ineffective if regional and local authorities can still introduce uncertainty by discretionary decisions that favor vested interests and protect rents. By contrast, proposals 2-4 emphasize IPR protection and can only be taken up by national or even supranational bodies with the power to (re)negotiate the international treaties that currently bind local and regional policymakers. 
Table 2.2 Summary of proposals regarding rule of law and property rights protection, specifying the level in the governance hierarchy where the necessary decisions should be made

\begin{tabular}{|c|c|c|c|c|}
\hline No. & Principle(s) & Policy area & Proposal & $\begin{array}{l}\text { Policy } \\
\text { level }^{\text {a }}\end{array}$ \\
\hline 1 & Legality & $\begin{array}{l}\text { The rule of } \\
\text { law }\end{array}$ & $\begin{array}{l}\text { Strengthen monitoring and enforcement } \\
\text { mechanisms to improve and safeguard } \\
\text { the performance of all member states on } \\
\text { rule of law, protection of property } \\
\text { rights, and government effectiveness. }\end{array}$ & $\begin{array}{l}\text { EU, } \\
\text { MS, } \\
\text { REG, } \\
\text { LOC }\end{array}$ \\
\hline 2 & Justifiability & $\begin{array}{l}\text { Patents and } \\
\text { intellectual } \\
\text { property }\end{array}$ & $\begin{array}{l}\text { Limit the breadth, width, and span of } \\
\text { patent protection to cover working } \\
\text { prototypes and market-ready } \\
\text { innovations only for a short period of } \\
\text { time, and permit economic actors to } \\
\text { infringe upon patents that have not } \\
\text { been commercialized. }\end{array}$ & EU, MS \\
\hline 3 & Justifiability & $\begin{array}{l}\text { Patents and } \\
\text { intellectual } \\
\text { property }\end{array}$ & $\begin{array}{l}\text { Require patent applicants to set the } \\
\text { price for the license before the } \\
\text { commercial application is known instead } \\
\text { of allowing them to negotiate the terms } \\
\text { of a license contract afterwards. }\end{array}$ & EU, MS \\
\hline 4 & Justifiability & $\begin{array}{l}\text { Patents and } \\
\text { intellectual } \\
\text { property }\end{array}$ & $\begin{array}{l}\text { Introduce and support existing } \\
\text { experiments with open source patent } \\
\text { registration. }\end{array}$ & $\begin{array}{l}\text { EU, } \\
\text { MS, } \\
\text { REG }\end{array}$ \\
\hline
\end{tabular}

aEU federal level, MS member state level, REG regional government level, LOC local/ municipal level

Open Access This chapter is licensed under the terms of the Creative Commons Attribution 4.0 International License (http://creativecommons.org/licenses/by/4.0/), which permits use, sharing, adaptation, distribution and reproduction in any medium or format, as long as you give appropriate credit to the original author(s) and the source, provide a link to the Creative Commons licence and indicate if changes were made.

The images or other third party material in this chapter are included in the chapter's Creative Commons licence, unless indicated otherwise in a credit line to the material. If material is not included in the chapter's Creative Commons licence and your intended use is not permitted by statutory regulation or exceeds the permitted use, you will need to obtain permission directly from the copyright holder.

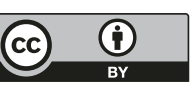

